\title{
ARTIKELEN
}

\section{Onderzoeksnotitie: Handhelds en arbeidsdeling in Nederlandse horecabedrijven}

\author{
Roel Schouteten, Jos Benders \& Céline de Ruijsscher
}

\begin{abstract}
Deze onderzoeksnotitie laat zien hoe en waarom de introductie van handhelds in Nederlandse horecagelegenheden een verdere arbeidsdeling in de hand werkt. Handhelds bieden mogelijkheden om de taken in de functie van de voormalige ober op te splitsen in twee verschillende functies: 'palmtoppers' (die bestellingen opnemen en afrekenen) en 'runners' (die bestellingen serveren). Hoewel deze arbeidsdeling in bijna alle gelegenheden werd toegepast zijn er uitzonderingen mogelijk. De resultaten laten zien dat de technologie weliswaar voorwaarden voor een bepaalde arbeidsdeling creëert, maar dat uiteenlopende afwegingen een rol spelen bij de uiteindelijke keuze voor een bepaalde functiestructuur. Deze studie geeft een overzicht van dergelijke afwegingen en factoren en van de onderliggende mechanismen die daarbij een rol spelen.
\end{abstract}

\section{Introductie}

Veel wetenschappelijke studies hielden, houden en zullen zich nog gaan bezighouden met het bestuderen van de invloed van de introductie van nieuwe technologie op de arbeidsverdeling in organisaties (Davis \& Taylor, 1976). Van oudsher domineren twee perspectieven het technologiedebat: technologisch determinisme en voluntarisme (Grint \& Woolgar, 1997). Deze kunnen worden gezien als de twee uiteinden van een continuüm. Ondanks de consensus onder sociale wetenschappers dat technologisch determinisme geen houdbare stelling is (Liker, Haddad \& Karlin, 1999), is het wel opvallend hoeveel onderzoek er nog steeds wordt gepubliceerd waarin een directe relatie tussen technologie en werkgerelateerde aspecten wordt verondersteld (Green, Felstead \& Gallie, 2003). Deze studies zijn vaak gebaseerd op grote kwantitatieve studies waarin niet of nauwelijks een onderscheid kan worden aangebracht tussen verschillende typen technologie, verschillende soorten organisatiestructuren en verschillende contexten (zie bijvoorbeeld de discussie tussen Kraan (2005; 2006) en Benders (2006) hierover in dit tijdschrift). Derhalve is het nog steeds interessant om te onderzoeken hoe technologiegebruik is gerelateerd aan arbeidsverdeling, en daarmee aan de functiestructuur en de daaruit resulterende functiekenmerken en -vereisten. Het doel van

* $\quad$ Roel Schouteten is werkzaam bij de Radboud Universiteit Nijmegen, Institute for Management Research. E-mail: r.schouteten@fm.ru.nl. Jos Benders is werkzaam bij de Katholieke Universiteit Leuven, CESO, en de Universiteit van Tilburg, Organisatiewetenschappen. Celine de Ruijsscher is werkzaam bij Talis, Nijmegen. 
deze onderzoeksnotitie is om na te gaan hoe en waarom de arbeidsverdeling verandert met de invoering van een nieuwe technologie.

Om dit te bestuderen is het noodzakelijk om een relatief eenvoudige technologie te bestuderen, zodat maar een beperkt aantal factoren tegelijkertijd verandert. Daarnaast is van belang dat dezelfde technologie in een groot aantal organisaties wordt gebruikt, zodat een vergelijkende analyse kan worden gemaakt van welke factoren een rol spelen. Een in onze ogen goed voorbeeld van een dergelijke technologie is het gebruik van handhelds in de horeca: deze zijn redelijk eenvoudig in het gebruik en worden op steeds grotere schaal toegepast, zodat er potentieel veel onderzoeksmogelijkheden zijn. Inmiddels zijn handhelds in de horeca, én in veel andere sectoren, gemeengoed. De snelle technologische ontwikkeling maakt dat er bijna continu nieuwe gebruiksmogelijkheden aan deze apparaten, én aan verwante technologieën als mobiele telefoons, worden toegevoegd. Onderzoek naar de gevolgen van nieuwe technologie en arbeidsverdeling mag dan ook permanent actueel worden genoemd (Batenburg, Benders \& Steijn, 2002). Empirisch gezien is er nog maar weinig onderzoek naar het gebruik van handhelds en de effecten daarvan op de organisatieprocessen (een uitzondering is Engels, 2007); in het gespecialiseerde tijdschrift International Journal of Mobile Communications verscheen in de periode 2008-2011 geen enkel artikel hierover. Er zijn wel studies over het ontwerp (Caus, Christmann \& Hagenhoff, 2009) of de acceptatie en het gebruik van mobiele systemen (Bouwman \& Van de Wijngaert, 2009), maar hierin wordt de arbeidsverdeling niet meegenomen. Dit resulteert in de volgende onderzoeksvraag voor deze onderzoeksnotitie: onder welke omstandigheden neemt de arbeidsverdeling toe of af na de introductie van handhelds in horecabedrijven?

In het vervolg van deze onderzoeksnotitie bespreken we eerst een conceptueel model om de relatie tussen technologie en arbeidsverdeling te kunnen bestuderen. Daarna gaan we in op de gebruikte methodologie, geven we nadere uitleg over handhelds en bespreken we de empirische resultaten. Ten slotte bespreken we onze conclusie.

\section{Het 'Takenpakket-model'}

Het conceptuele uitgangspunt voor dit onderzoek is het zogenaamde 'Takenpakket-model' (Benders, 1993; Batenburg, Benders \& Steijn, 2002). Het 'takenpakket' bestaat uit alle taken in de organisatie die (nog) door mensen moeten worden verricht. Bij functieontwerp worden deze taken verdeeld over functies. Daartoe wordt er, impliciet of expliciet, gebruikgemaakt van ontwerpprincipes. Twee uitersten daarin zijn fragmentatie en integratie. Bij integratie wordt ernaar gestreefd om uitvoerende, voorbereidende en ondersteunende taken te combineren, zodat er volledige functies (Hacker, 1989) ontstaan waarin werknemers ook zeggenschap over hun eigen werk hebben. Vanuit het fragmentatieprincipe wordt er, daarentegen, naar gestreefd om taken zo veel mogelijk over verschillende functies te verdelen, resulterend in een hoge mate van arbeidsdeling. De belangrijkste rol van technologie in het takenpakket-model is dat de introductie van 


\section{Figuur 1 De invloed van technische systemen op de functiestructuur}

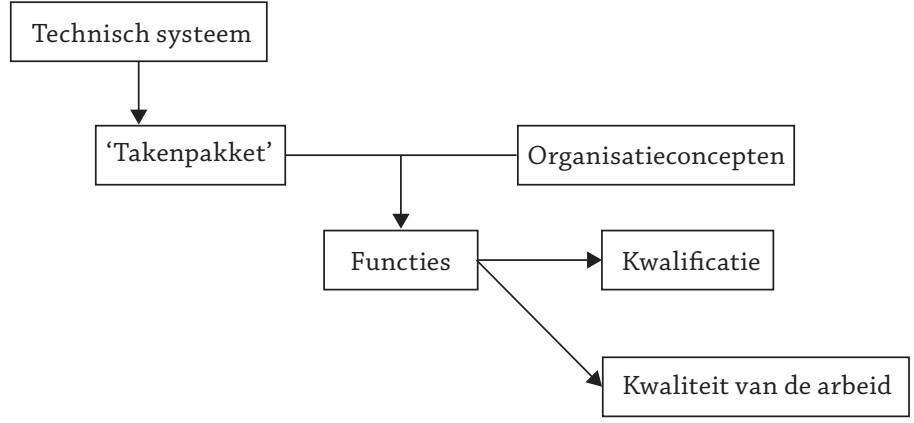

nieuwe technologie zorgt voor wijzigingen in de taken die (nog) door mensen gedaan moeten worden. Enerzijds wordt door nieuwe technologie werk gemechaniseerd dat eerst handmatig werd gedaan. Daarnaast ontstaan er vaak nieuwe taken in de vorm van bedieningstaken (vgl. Davis \& Taylor, 1976: 388). Figuur 1 geeft deze redenering schematisch weer.

Als het takenpakket uit taken met verschillende moeilijkheidsgraad bestaat, ligt het voor de hand dat er functies van verschillend niveau worden gecreëerd. Vaak worden eenvoudige taken, zoals machine-invoer, gecombineerd tot functies. Ook meer ingewikkelde taken, zoals machineonderhoud, worden vaak tot functies gecombineerd. De logica hierachter is dat het salaris van werknemers vaak wordt bepaald op basis van de hoogste vereiste kwalificatie. Door eenvoudige taken te combineren ontstaan er dus goedkope arbeidsplekken. Hiermee is het in de hand houden van arbeidskosten een belangrijke drijfveer achter gefragmenteerde arbeidsverdelingen.

\section{Handhelds}

Een 'handheld computer', 'palmtop' of 'personal digital assistant' (PDA) kan worden gedefinieerd als een digitale machine (computer) die is ontworpen om in de hand te houden en te bedienen (Myers, 2005: 252). In de horeca worden handhelds vooral aangeschaft als een uitbreiding van geautomatiseerde barsystemen. Deze systemen kunnen variëren van relatief eenvoudige digitale kassasystemen tot organisatiebrede systemen inclusief automatische tapsystemen en voorraadbeheer. Ten tijde van het onderzoek (2007) kostten handhelds ongeveer $€ 700$ tot $€ 1.300$ per stuk. Een geautomatiseerd barsysteem kostte toen ongeveer $€ 10.000$ à $€ 15.000$.

Op de websites van aanbieders van handhelds worden diverse voordelen van dergelijke systemen benoemd (De Ruijsscher \& Victoria, 2006: 11):

- Tijdbesparing (snellere bezorging van bestellingen)

- Meer service 
- Hogere omzet

- Lagere kosten

- Eenvoudiger taken

- Verbeterde controlemogelijkheden

- Minder fouten

- Kwaliteit van het werk.

In deze opsomming zijn de economische motieven (vaak onderling gerelateerd) erg dominant. Snellere levering van bestellingen betekent een hogere tafelbezetting, en dus meer omzet. Daarnaast wordt er tijd (en kosten) bespaard doordat de bediening niet meer voortdurend heen en weer hoeft te lopen tussen terras/tafels en bar/keuken om een bestelling door te geven. Verbeterde controle, zowel in termen van minder fouten als strakkere aansturing van personeel, wordt slechts sporadisch (10-15\% van de websites) genoemd. Kwaliteit van het werk werd het minst vaak als voordeel genoemd. Scornavaca, Prasad \& Lehmann (2006) stellen dat de efficiency van het bestelproces het belangrijkste voordeel van dergelijke systemen is. Dit wordt versterkt door het inzetten van minder gekwalificeerd personeel (kostenbesparing).

Deze lijst van benoemde voordelen roept echter wel de vraag op hoe deze beoogde effecten gerealiseerd kunnen worden. Voor een antwoord daarop is het noodzakelijk om na te gaan op welke manier taken over functies verdeeld kunnen worden en welke arbeidsverdelingen er in horecagelegenheden mogelijk zijn.

\section{Methode}

In totaal hebben we 15 horecabedrijven met handhelds bestudeerd. Bij de selectie daarvan hebben we gestreefd naar een diversiteit aan factoren die van invloed kunnen zijn op keuzes over de arbeidsverdeling bij het gebruik van handhelds. In het onderzoek zijn daarom verschillende soorten bedrijven vertegenwoordigd (lunchroom, café, grand café, restaurant): de idee hierachter is dat hier uiteenlopende klantbenaderingen zijn te verwachten, die van invloed kunnen zijn op de arbeidsverdeling. Verder varieert de bedrijfsgrootte, omdat arbeidsverdeling gerelateerd is aan de hoeveelheid werk. De keuze voor verschillende Nederlandse steden was primair een pragmatische; wel zijn de meeste bedrijven in Nijmegen gesitueerd, en wilden we vermijden dat specifiek Nijmeegse omstandigheden, zoals de beschikbaarheid van studenten op de arbeidsmarkt, onze resultaten zouden beïnvloeden. Tabel 1 bevat een overzicht van de bestudeerde horecagelegenheden en hun belangrijkste kenmerken.

De dataverzameling heeft plaatsgevonden door middel van een gestructureerde interviewlijst met horecapersoneel (voornamelijk leidinggevenden). In de interviews is aandacht besteed aan organisatiekenmerken, de kenmerken van de handheld en het gebruik ervan, en de (al dan niet daaruit voortvloeiende) arbeidsverdeling. Daarbij werd ook gevraagd naar de achtergronden van impliciet of expliciet gemaakte keuzes. De uitgeschreven interviewverslagen zijn ter controle 
aan de respondenten voorgelegd en waar nodig aangepast voordat ze zijn geanalyseerd.

Daarnaast, voornamelijk voorafgaand aan de interviews, hebben er terloopse observaties in de betreffende gelegenheden plaatsgevonden. Hiermee werd een rijk inzicht verkregen in mogelijke factoren die een rol spelen bij het gebruik van deze relatief eenvoudig te gebruiken technologie. In de interviews kon dan naar een verduidelijking of de achtergrond van de geobserveerde situatie worden gevraagd.

\section{Mogelijke arbeidsverdelingen}

Oorspronkelijk bestond het werk van bedienend personeel in de horeca (obers, serveersters) uit drie hoofdtaken: opnemen van bestellingen, serveren van bestellingen en afrekenen. Het bedienen van de handheld is een nieuwe taak als gevolg van de invoering van deze nieuwe technologie. Het is geen ingewikkelde taak, maar enige computervaardigheden zijn noodzakelijk en daarmee ook enige instructie voordat ermee gewerkt kan worden.

Als bestellingen zijn opgenomen worden ze ingevoerd in het systeem (de handheld) en wordt de bestelling meteen doorgestuurd naar de bar (of de keuken). Daar wordt de bestelling meteen klaargemaakt waarna de bestelling naar de betreffende tafel wordt gebracht. Het klaarmaken van de bestelling is meestal een aparte functie van barmedewerker (of kok of keukenhulp). Het afrekenen gebeurt meestal als klanten weggaan, wanneer de hele rekening per tafel/klant kan worden opgemaakt.

De introductie van handhelds maakt het mogelijk de drie hoofdtaken over verschillende functies te verdelen. De taken van de ober kunnen over twee verschillende functies worden verdeeld: 'palmtopper' en 'runner'. De palmtopper neemt bestellingen op en rekent af. Runners brengen alleen bestellingen en ruimen tafels af. Analytisch gezien kunnen we dus een onderscheid maken naar een geïntegreerde functie (optie I) en een meer gefragmenteerde verdeling met een splitsing tussen palmtopper en runner (optie $S$ ).

\section{Resultaten}

\section{Functiestructuur}

In bijna alle 15 bestudeerde bedrijven is de gesplitste functiestructuur (optie $S$ ) gevonden (zie tabel 1). Een eerste conclusie daaruit zou kunnen zijn dat de mogelijkheid om door het gebruik van handhelds de oorspronkelijke functie op te splitsen ook daadwerkelijk bijna altijd wordt gebruikt. 


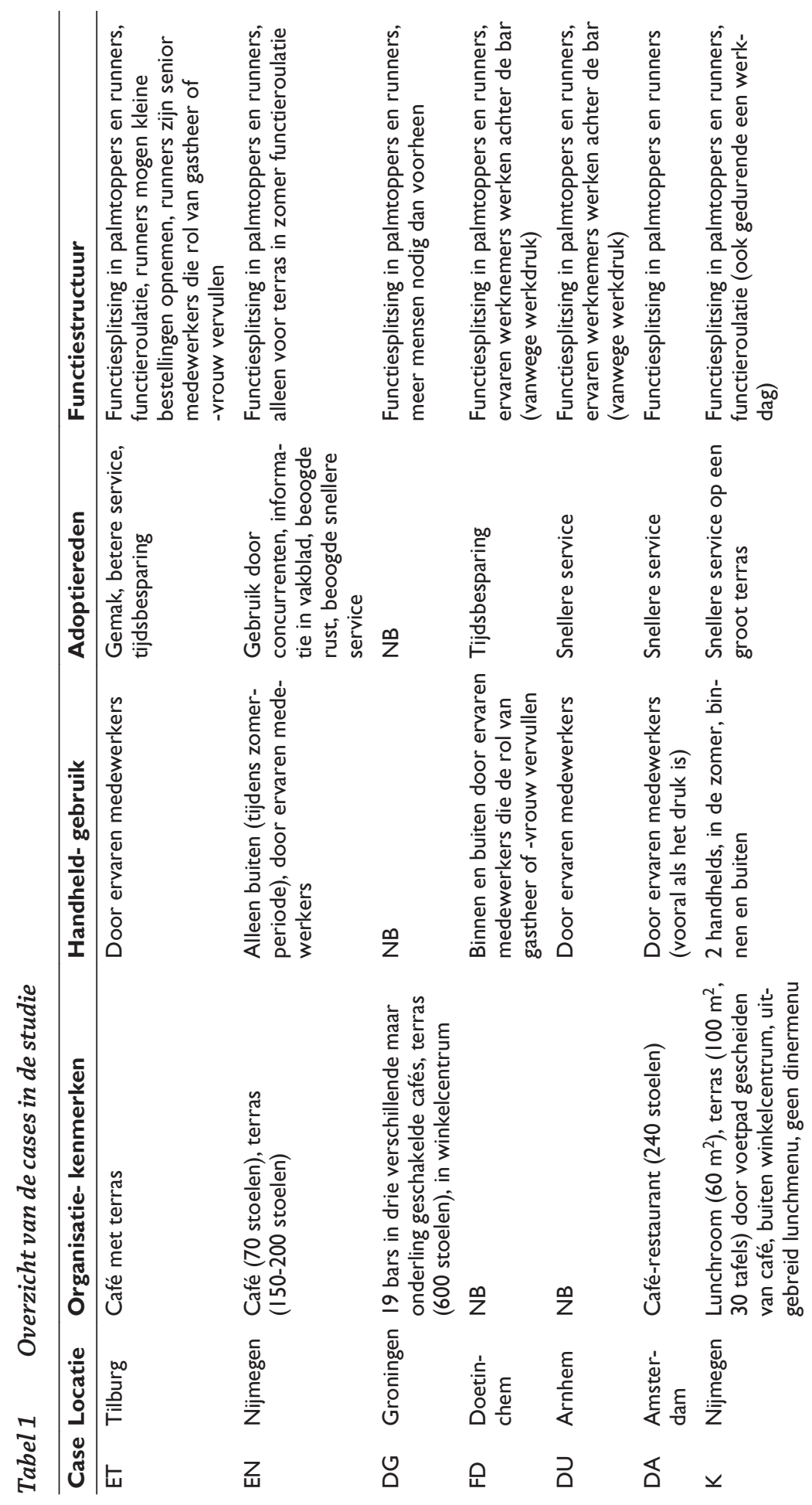




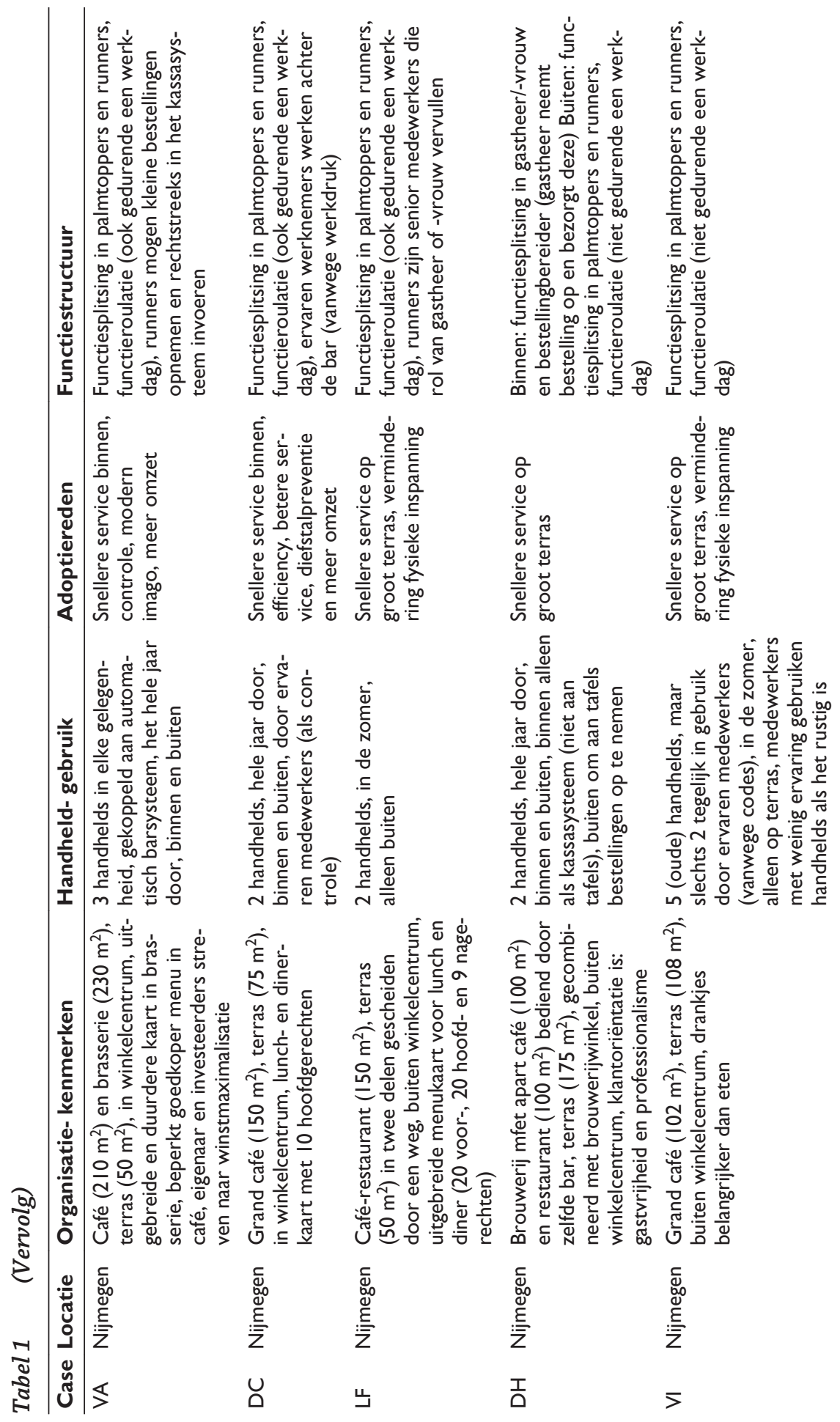




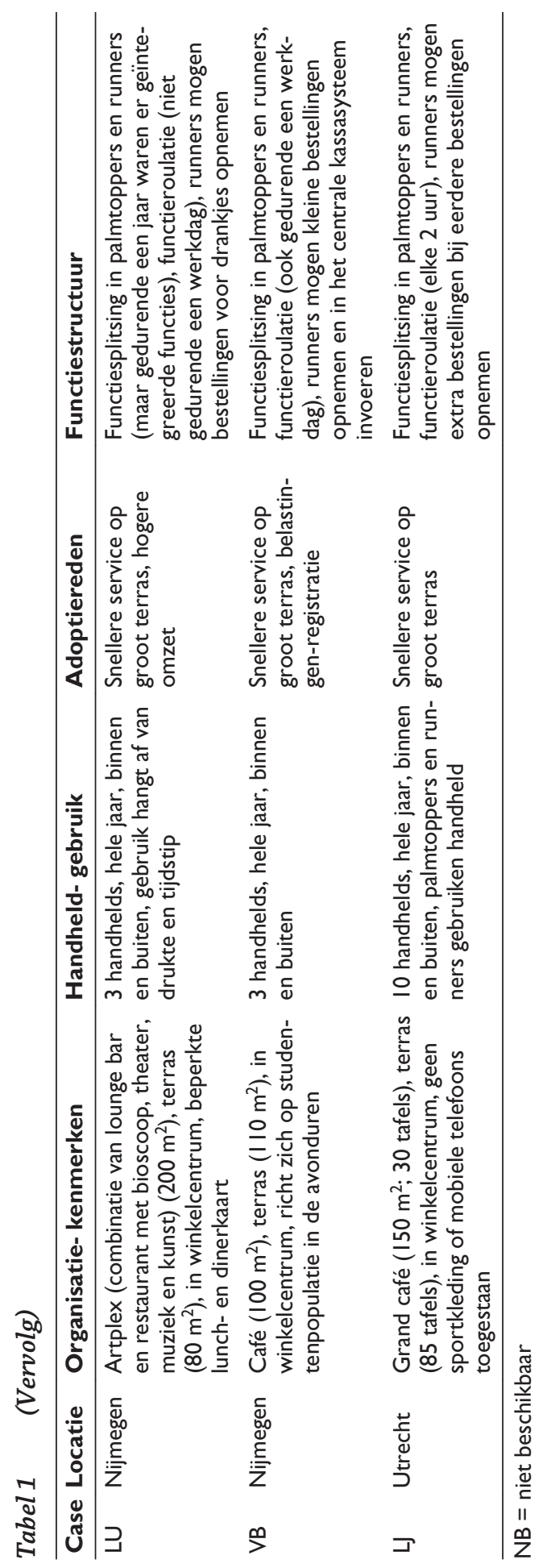


We hebben echter ook gevonden dat de keuze voor gesplitste functies niet automatisch inhoudt dat de functies van palmtopper en runner vast zijn. Functieroulatie is een normaal fenomeen. Voorafgaand aan het werk worden de taken onder de aanwezige personeelsleden verdeeld, waarbij rekening wordt gehouden met het werk dat gedaan moet worden en persoonlijke voorkeuren. Ook tijdens het werk treedt er vaak nog functieroulatie op. Dit betekent dat de arbeidsverdeling gericht is op functies; niet op personen. Er worden dus verschillende functies gecreëerd, maar de medewerkers wisselen de verschillende functies af (zowel tijdens een werkdag als op verschillende dagen). Het komt daarbij wel voor dat nieuwe medewerkers niet meteen de functie van palmtopper, barmanager of gastheer of -vrouw toegewezen krijgen, maar functieroulatie is over het algemeen de norm. Dit betekent dat verlaging van de arbeidskosten nauwelijks een argument is om voor de gesplitste arbeidsverdeling te kiezen. Het salaris is meer afhankelijk van leeftijd en ervaring dan van de taken die worden verricht. Hierbij spelen wettelijke bepalingen rondom de inzet van jongeren een belangrijke rol: medewerkers die nog geen 18 jaar zijn mogen niet met alcohol werken en niet later werken dan 23.00 uur.

Aangezien personeelskosten nauwelijks een reden zijn om voor de gesplitste arbeidsverdeling te kiezen, rijst de vraag waarom in bijna alle organisaties voor de gesplitste structuur is gekozen.

\section{Adoptieredenen}

Het antwoord ligt in de meest dominante reden om over te gaan tot de aanschaf van handhelds: snelheid van bediening. Dit werd door alle bedrijven als belangrijkste en vaak als enige reden genoemd voor de aanschaf van de technologie. Vooral grotere gelegenheden (met grote terrassen) en drukke gelegenheden (in winkelcentra) vinden snelheid van bediening uitermate belangrijk. Daarnaast werden ook de algemene termen 'efficiency' en 'betere service' genoemd, maar ook: het voorkomen van diefstal (casus DC) of controle over het weggeven van drankjes (casus VA), een modern imago (casus VA), fysiek minder zwaar werk (cases VI en LF), belastingregistratie (casus VB), imitatie van concurrenten (casus $\mathrm{EN}$ ) en kortere inwerktijden voor met name de runnersfunctie (casus D). Snellere bezorging van bestellingen kan resulteren in een hogere omzet per tafel: klanten worden sneller geholpen en gaan sneller weer weg (om plaats te maken voor nieuwe klanten; vooral in winkelcentra) of ze bestellen meer tijdens het verblijf (vooral in gelegenheden buiten de winkelcentra). Sommige bedrijven geven aan dat daardoor de totale omzet is gestegen.

Aangezien snellere bediening als belangrijkste adoptiereden wordt genoemd is het noodzakelijk om nader te bestuderen wat dit betekent voor de werkprocessen en werkverdeling. Snellere bediening kan gemakkelijker worden gerealiseerd als het opnemen en bezorgen van bestellingen wordt gesplitst. Degene die de bestelling opneemt hoeft dan niet eerst naar de bar te lopen om een bestelling op te halen. In de plaats daarvan kan een runner die taak vervullen. Dit voordeel is groter naarmate de gelegenheid en het bijbehorende terras groter zijn, zeker als ook in 
ogenschouw wordt genomen dat vaak eerst meerdere bestellingen (van verschillende tafels) worden opgenomen voordat de medewerker naar de bar gaat om bestellingen op te halen en te serveren. De snelheid van afleveren van bestellingen neemt zelfs al toe (ten opzichte van de situatie zonder handheld) als de degene die de bestelling opneemt deze ook zelf bezorgt, want de bestelling kan al worden klaargemaakt terwijl de ober/serveerster naar de bar terugloopt. Maar dat voordeel is dus groter als een runner de bestellingen brengt en een palmtopper alleen bezig is met het opnemen van bestellingen. Twee bedrijfsleiders hebben echter wel aangegeven dat het werken met aparte runners duurder is, omdat er een extra medewerker beschikbaar moet zijn.

\section{Pieken en dalen}

Gedurende de openingstijden kan de arbeidsverdeling veranderen. Zowel gedurende een dag als tussen seizoenen is het werk onderhevig aan pieken en dalen. Tijdens lunch- en etenstijd is het bijna altijd erg druk, terwijl het tussendoor een stuk rustiger kan zijn. En de bezetting van terrassen is erg weersafhankelijk. Deze variatie blijkt van invloed te zijn op de gekozen functiestructuur en arbeidsverdeling. De meeste gelegenheden hebben zowel vast als flexibel inzetbaar personeel, waarbij de laatste categorie vooral wordt ingezet op drukke tijden. Dit zijn vaak de minder ervaren medewerkers die daarom vaak ook minder verantwoordelijke taken krijgen toebedeeld. Vertaald naar de functiestructuur betekent dit dat deze minder ervaren medewerkers vaak de rol van runner vervullen (meestal op buitenterrassen in het zomerseizoen). Hieruit kunnen we concluderen dat bij drukte (a) er een splitsing plaatsvindt van palmtoppers en runners, en (b) de functie van runner vaak door de meest onervaren medewerkers wordt vervuld.

Het eenvoudige karakter van de meeste bedieningstaken maakt dat ze eenvoudig uitwisselbaar zijn. Met een lage of nagenoeg afwezige inleertijdbarrière (Benders, 1990) kunnen de verschillende taken gemakkelijk door andere personen worden overgenomen. Hiermee is de rol van functieroulatie tamelijk beperkt: er wordt geen onderscheid naar functies gemaakt vanwege de verschillende vereiste kwalificaties (kennis en vaardigheden), maar vanwege het feit dat functiesplitsing leidt tot snellere dienstverlening. In de onderzochte horecagelegenheden verloopt deze functieroulatie erg soepel en nemen de medewerkers elkaars taken snel en gemakkelijk van elkaar over.

Vanwege de pieken en dalen in het werk en vanwege de hoge kosten hebben de meeste gelegenheden maar een beperkt aantal handhelds aangeschaft. Ook dit is van invloed op de arbeidsverdeling. Als het drukker wordt, wordt er meer personeel ingezet, maar niet iedere medewerker kan beschikken over een handheld. In die gevallen treedt automatisch een splitsing naar palmtoppers en runners op.

\section{De uitzonderingen: geïntegreerde functies}

Het is bijzonder interessant om de uitzonderingen op het eerder beschreven patroon nader te bestuderen. In drie gelegenheden zien we uitzonderingen: 
Roel Schouteten, Jos Benders \& Céline de Ruijsscher

casus $\mathrm{H}$ is een gecombineerd bar-restaurant, casus LU is een grote bar met een groot terras, en casus LJ beschikt over maar liefst 10 handhelds.

Casus $\mathrm{H}$ is begonnen als een kleine brouwerij die gaandeweg is uitgebreid met andere activiteiten, waaronder een restaurant. De bar/brouwerij en het restaurant gebruiken hetzelfde informatiesysteem. Het bedrijf positioneert zichzelf als een kwaliteitshorecagelegenheid, met goed gekwalificeerd personeel met kennis van zaken over, met name, de zelfgebrouwde bieren. Daarnaast staat klantvriendelijkheid hoog in het vaandel. Mede daarom heeft het management lange tijd geaarzeld met de aanschaf van handhelds; er werd voor gevreesd dat de medewerkers meer met de handhelds bezig zouden zijn dan met de klanten. Dit is nog steeds een belangrijke zorg, hoewel de handhelds al meer dan een jaar voor deze studie werden aangeschaft.

De handhelds worden gedurende het hele jaar gebruikt. Opvallend is dat één van de handhelds wordt gebruikt als een soort kassasysteem, omdat de aanschaf van een compleet IT-systeem daartoe drie keer zo duur zou zijn. Alle restaurantbestellingen worden via de handheld ingevoerd, maar daartoe wordt de handheld niet aan de tafels gebruikt. In plaats daarvan ligt de handheld bij de ingang, neemt het personeel aan tafel de bestelling op en voert deze daarna in in de handheld bij de ingang van het etablissement. In het bargedeelte staat er een volledig pckassasysteem. De tweede handheld wordt alleen gebruikt als het buitenterras is geopend. Buiten wordt de handheld wel aan tafels gebruikt om bestellingen in te voeren. Echter, als het erg druk is voldoen de twee handhelds niet en worden de medewerkers zonder handheld de facto runners. Zij nemen dan soms wel bestellingen op, maar geven deze door aan de palmtoppers.

In casus LU, een bar met een groot terras, werden de handhelds in 2002 aangeschaft als een uitbreiding van het al aanwezige geautomatiseerde informatiesysteem. Aanvankelijk was er gekozen voor gesplitste functies van palmtoppers en runners om het proces van bestellen en serveren te versnellen. Daarbij was er ook voor gekozen om klanten reeds bij bestelling te laten betalen. De bestelling werd dan later door de runner geserveerd. Maar er werden vaak fouten gemaakt en het bedienend personeel kreeg veel klachten, ook over het meteen betalen bij bestelling. Daarnaast vonden de medewerkers het niet leuk om alleen bestellingen te serveren en dus alleen heen en weer te lopen tussen bar en tafels. De personeelssamenstelling in deze organisatie was redelijk stabiel. Om de betrokkenheid van het personeel te verhogen en gevoed door klachten van klanten werd de arbeidsverdeling veranderd: de voormalige runners werden ook van handhelds voorzien, zodat er weer geïntegreerde functies ontstonden (bestellen, serveren, afrekenen). De medewerkers in de bediening kregen elk weer hun eigen 'district' op het terras, net zoals vóór de invoering van de handhelds. Deze verandering werd dus ingegeven door de wens om klanten tevreden te houden. Echter, met de komst van een nieuwe bedrijfsleiding is er toch weer gekozen voor splitsing van functies in palmtoppers en runners. De nieuwe leiding geeft de voorkeur aan een zo efficiënt mogelijk proces. Om klanten tevreden te houden kunnen deze wel pas achteraf 
betalen en kunnen ze ook bestellingen doorgeven aan runners. Deze manier van werken wordt via tafelkaarten aan klanten duidelijk gemaakt.

Het meest opvallende aan casus LJ is het relatief grote aantal van tien handhelds; de meeste bestudeerde organisaties hebben twee tot vijf handhelds. Net zoals in de meeste andere organisaties gebruikt men een systeem van palmtoppers en runners, maar hier hebben de runners ook een handheld. De idee is dat klanten hun bestellingen doorgeven aan palmtoppers die voortdurend op het terras aanwezig zijn. De bestelling moet dan bij voorkeur binnen een minuut worden geserveerd. Het komt echter vaak voor dat klanten bij levering van de bestelling nog meer willen bestellen. Om wachttijden te vermijden kan een runner deze extra bestellingen opnemen en invoeren. Een bijkomende, maar minder belangrijke reden is dat men de suggestie wil voorkomen dat klanten niet goed worden behandeld. Daarmee fungeren de runners in deze organisatie als een extra, maar niet standaard bestelpunt. Opmerkelijk hierbij is dat de functie van deze runners, als ze ook bestellingen opnemen, completer (meer volledig) is dan die van de palmtoppers. Ten slotte, de medewerkers wisselen elke twee uur van functie om te voorkomen dat runners fysiek uitgeput raken.

\section{Conclusie}

De introductie van nieuwe technische systemen is vaak van invloed op de bestaande functiestructuur. Een nieuw technisch systeem is van invloed op de (aard van de) taken die door mensen gedaan moeten worden (takenpakket); sommige handmatige taken vervallen, maar daarvoor komen bedieningstaken in de plaats. Bij het gebruik van handhelds in de horeca wordt het bestelproces geautomatiseerd: bestellingen worden automatisch doorgegeven aan de bar of de keuken op het moment dat ze worden ingevoerd, rekeningen kunnen automatisch worden gegenereerd, en alle financiële gegevens worden automatisch opgeslagen in de boekhoudmodule van het systeem. In principe zou het werk van bedienend personeel daardoor niet of nauwelijks hoeven te veranderen. Het enige verschil is dat bestellingen moeten worden ingevoerd in een handheld en dat ze niet meer fysiek naar een centrale plek moeten om een bestelling door te geven door invoering in het systeem. Ons onderzoek laat echter zien dat, met enkele uitzonderingen, bijna alle horecagelegenheden in dit onderzoek hebben gekozen voor de optie om het werk te verdelen over de functies van palmtopper (die de bestelling opneemt) en runner (die de bestelling serveert).

Deze splitsing van functies wordt door de technologie mogelijk gemaakt: de nieuwe technologie lijkt ertoe te leiden dat voormalig geïntegreerde functies worden gesplitst in afzonderlijke functies. In principe is een dergelijke splitsing ook mogelijk zonder handhelds, maar dat komt zelden voor omdat het als niet efficiënt wordt beschouwd. Toch zijn er nog enkele voorbeelden en situaties waarin (bewust) niet voor gesplitste functies wordt gekozen. Bij drie organisaties is bewust voor geïntegreerde functies gekozen vanwege, respectievelijk, een strate- 
gisch visie over de marktpositionering en vanwege medewerker- en klantreacties (klachten).

Overigens wijkt de economische logica voor een gesplitste arbeidsverdeling af van wat veelal wordt verondersteld. De winst wordt niet gehaald met het lager inschalen van de nieuwe eenvoudige functie van runner, maar met het verhogen van de omzetsnelheid.

Hiermee ontstaat het beeld dat een toegenomen arbeidsdeling door functiesplitsing het automatische gevolg is van de invoering van handhelds in de horeca. Een alternatieve arbeidsverdeling is mogelijk, maar komt slechts in enkele uitzonderingen voor. Echter, als het niet zo druk is wordt er vaker voor de geïntegreerde optie gekozen. Daarmee wordt de arbeidsverdeling dus aangepast aan de mate van behoefte aan arbeidscapaciteit. Hiermee kunnen we concluderen dat de arbeidsverdeling mede afhankelijk is van:

- de drukte

- het aantal handhelds in relatie tot het aantal medewerkers.

Als voldoende handhelds aanwezig zijn kunnen alle medewerkers ermee worden uitgerust. Hoe drukker het wordt, hoe groter de kans dat dit niet (meer) lukt, omdat het aantal handhelds per organisatie meestal beperkt is. Maar ook als alle medewerkers een handheld hebben is de kans aanwezig dat de bestelling door een andere medewerker wordt geserveerd dan degene die de bestelling opnam. In de praktijk blijkt dus dat de introductie van de handhelds een grotere mate van arbeidsdeling in de hand werkt. Het door technologie mogelijk maken van functiesplitsing is de dominante logica gebleken.

De conceptuele betekenis van dit onderzoek is dat de arbeidsdeling na de introductie van een technisch systeem wordt bepaald door een combinatie van (elkaar deels aanvullende) factoren. De economische motieven voor het gebruik van de technologie en de contextuele factoren spelen een rol bij de keuze voor welke functieverdeling op welk moment het beste werkt. Zelfs in het geval van een relatief eenvoudige technologie in de horeca spelen vele factoren een belangrijke rol. Elk onderzoek dat de relatie tussen technologie en functiestructuur en taakkenmerken wil bestuderen zal zulke factoren in beschouwing moeten nemen. Daar waar grote kwantitatieve onderzoeken wel correlaties tussen technologie en functiestructuur vinden, maar tekortschieten in het duiden van deze relaties, biedt dit onderzoek inzicht in verklaringen over waarom sommige keuzes overheersen, maar dat alternatieven ook mogelijk zijn. Onze bevindingen wijzen erop dat het wenselijk is om de aard van de arbeidsverdeling mee te nemen in toekomstig kwantitatief onderzoek naar de effecten van de inzet en het gebruik van technologie, en niet te volstaan met het meten van enkel de aanwezigheid daarvan.

Een methodologische beperking is dat we geen vergelijkend onderzoek hebben gedaan tussen bedrijven mét en zonder handhelds. De vraag is of bedrijven zonder handhelds inmiddels niet óók hebben gekozen voor gesplitste functies. Omdat we wel hebben gevraagd naar de verandering ten opzichte van de situatie 
van vóór de invoering van handhelds, vermoeden we echter dat onze conclusies stand zullen houden in vergelijkend onderzoek.

Voor beleidsmakers en managers - zowel in de horeca als daarbuiten - laten onze bevindingen zien dat de introductie van nieuwe technologie, weliswaar indirect, van invloed is op de arbeidsverdeling. Maar er is altijd ruimte om een functiestructuur te ontwerpen die past bij de organisatiedoelen of specifieke organisatiekenmerken.

\section{Referenties}

Batenburg, R., Benders, J. \& Steijn, B. (2002). ICT en arbeid: nieuwe techniek, andere arbeidsvraagstukken? Tijdschrift voor Arbeidsvraagstukken, 18, 212-225.

Benders, J. (1990). Over de inzetbaarheid van werknemers, Tijdschrift voor Politieke Ekonomie, 13, 94-106.

Benders, J. (1993). Optional Options: Work Design and Manufacturing Automation. Aldershot: Avebury.

Benders, J. (2006). Het had ook anders kunnen zijn. Een reactie op Kraan (2005). Tijdschrift voor Arbeidsvraagstukken, 22, 203-204.

Bouwman, H. \& Van de Wijngaert, L. (2009). Coppers context, and conjoints: a reassessment of TAM. Journal of Information Technology, 24, 186-201.

Caus, T., Christmann, S. \& Hagenhoff, S. (2009). Development of context-aware mobile services: an approach to simplification. International Journal of Mobile Communications, 7, 133-153.

Davis, L.E. \& Taylor, J.C. (1976). Technology, Organization and Job Structure', In: R. Dubin (Ed.), Handbook of Work Organization and Society, (pp. 379-419). Chicago: Rand McNally College Publishing.

Engels, B. (2007). De autonome operator. Master Thesis, Radboud University Nijmegen, Nijmegen, The Netherlands.

Green, F., Felstead, A. \& Gallie, D. (2003). Computers and the changing skill-intensity of jobs. Applied Economics, 35, 1561-1576.

Grint, K. \& Woolgar, S. (1997). The Machine at Work; Technology, Work and Organization. Cambridge: Polity Press.

Hacker, W. (1989). Vollständige vs. unvollständige Arbeitstätigkeiten. In: Arbeits- und Organisationspsychologie (pp. 463-466). München: Psychologie Verlags Union.

Kraan, K. (2005). Complex en divers ICT-gebruik binnen vier organisatietypen. Verschillen in kwaliteit van de arbeid? Tijdschrift voor Arbeidsvraagstukken, 21, 269-283.

Kraan, K. (2006). Het is zoals het is en niet anders. Onderzoeken of ontwerpen? Tijdschrift voor Arbeidsvraagstukken, 22, 205-207.

Liker, J.K., Haddad, C.J. \& Karlin, J. (1999). Perspectives on technology and work organization. Annual Review of Sociology, 25, 575-596.

Myers, B.A. (2005). Using handhelds for wireless remote control of PC's and appliances. Interacting with computers, 17, 251-264.

Ruijsscher, C. de \& Victoria, H. (2006). 'Tijd voor techniek op het terras? Een onderzoek naar de redenen die aanbieders van handhelds aandragen op het Internet'. Paper voor de cursus Technologie, Arbeid en Organisatie, opleiding Bedrijfswetenschappen Radboud Universiteit Nijmegen. 
Roel Schouteten, Jos Benders \& Céline de Ruijsscher

Scornavacca, E., Prasad, M. \& Lehmann, H. (2006). Exploring the Organizational Impact and Perceived Benefits of Wireless Personal Digital Assistants in Restaurants. International Journal of Mobile Communications, 4, 558-567. 